\title{
Impact of Fuel Price Increaseon the Nigerian Economy
}

\author{
Stephen Ikani Ocheni, Ph.D., FCNA, ACTI
}

Department Of Accounting, Kogi State University, Anyigba

Email: stephenocheni@yahoo.com

\section{Doi:10.5901/mjss.2015.v6n1s1p560}

\begin{abstract}
Everybody appreciates the fact that when motorists pay more for fuel, the transport fare increases. This has been the case even when the increase is only marginal. In the particular case where the cost of fuel is expected to double, the increase in transport fare will be astronomical. This will in turn affect everything else - school fees, house rent, just name it. Therefore, this study took a critical look at the impact of Fuel price increase on the Nigerian economy(Whether negative or positive). The study adopted a survey research design approach to evaluate the level of effect the fuel price increase has on the Nigeria economy. The population of the study is made up of Civil Servants -CS, market men and women-MMW and staff in the private sectorsSPS concerned with petrol and gas affairs. A sample size of 120 persons was selected at random. It was distributed as follows: Civil Servants (18), market men and women (55) and staff in the private sectors (47). A pre test was conducted and outcome yield " $r$ "= 0.92 indicating a high degree of consistency and reliability. The instrument was 8- term survey questionnaire with a - 5 Likert scale response options of Very Relevant (VR), Relevant (R), No Effect (NE) Irrelevant (I), and Very Irrelevant (VI). The questionnaire was structured in line with the research objectives, questions and hypothesis of the study. The Pearson product moment correlation coefficient was used to confirm formulated hypotheses. Finding revealed that there is a significant relationship between the recent increases in fuel prices and economic growth in Nigeria. It was also discovered that the Nigeria economy is not developing because of the effect of fuel price hike on purchasing power and finally the finding showed that there is significant relationship between increase in pump price of petroleum and food security. The paper therefore recommended that Government should retain fuel subsidy while expediting the construction of the three proposed refineries; Fuel subsidy should be removed as soon as these new refineries are commissioned; the proposed rehabilitation of the existing refineries should be expedited; Government should vigorously pursue the revitalization of the railways. If only Nigerians had alternative to road transport, all this noise about fuel subsidy removal would not have been there and Private companies should be encouraged to start building refineries now with the assurance that subsidy would be removed before they start production.
\end{abstract}

Keywords: Fuel Subsidy, Fuel Scarcity, Economy, Nigeria

\section{Introduction}

Until the early 70's, the mainstay of Nigeria economy was agriculture. Then the country was famed for her proficiency in the production of groundnuts hence the Kano groundnut pyramids, oil palm and the faster part of cocoa in the western part of the country. The discovery of oil in the country in commercial quantities brought about radical changes in the economy of the nation. All other sectors seemed to have gone into oblivion and indeed were abandoned thereby making the country to be totally dependent on oil for her foreign exchange earnings; not agriculture any more. All effort made since then to diversify the economy of the country have come to naught. Expectedly the narrowing of the economy to a monolithic export commodity has its attendant drawback as oil by virtue of its importance to the economics of nations has inevitably become a subject of political manipulation. But the greater danger for Nigeria is that as a sole commodity of the nation and the inherent total dependency on oil has made the country's economy revolve around it. Virtually all essential service rendered in the country revolves it. Almost all other sectors of the economy depend on oil.Any contemplation therefore of a possible scarcity or unavailability of the product will no doubt spell doom for the economy of the country (Sikkam, 2009).

Yemi(2012) opined that full scarcity has plagued the nation recently appeared to be worse at the beginning of these years it caused a lot pain anguish and dislocation of economic and sundry activities. There was hardly any individual industries institutions and organization in Nigeria today that was not severely affected. It is widely believed in government circles what perennial fuel crisis is largely caused bottlenecks in the distribution system. But a survey show that the bottlenecks and other associated problem are caused by conflicting activities of multifarious government agencies.

Besides there are problem of manpower shortage inadequate funding lack of materials legal limitation and safely of 
personnel which officials explained have hundred departments to petroleum resources (DPR) in the petroleum products which increase the crisis in Nigeria despite the effort of DPR some encourage and sell adulterated fuel(Nwankwor,1981). The crisis situation worsening day after day when some fuel stations sold fuel in the night to the a black markets in which they will increase the rate from N350 to N500 per gallon depending on the level on the level of adulteration with kerosene. The fuel scarcity was believed to be worse in certain occasions by hoarding fuel diversion smuggling and under deliver at retails outlets have been rampant with the overall co-operation monitoring and general supervision of product random sampling at several filling stations and observed that the perennial fuel shortage was caused by filling stations. Despite all the efforts of the ministry and parastatals the NNPC has almost found it impossible to eliminate the activities of saboteurs in the oil industry in the country. Investigation has shown that between January and March 1999 Nigeria has had a daily local consumption of 8.509 million liters of fuel supported with 6.883 million liters imported fuel thereby bringing the product available to 15.392 million litters. Allwell (2012) suggests that smugglers and saboteurs in the country contributed so much to the scarcity.

Despite the NNPC official attempt to arrest the lingering fuel crisis culminating in the first even "operation crush" nationwide exercise the problem has refuse to go.The station is blamed on the activities of economic saboteurs who divert greatest percent of the fuel supply meant for daily consumption to the black market. Nwosu(2009)said that as long as poor pricing of petroleum product the high pricing in neighboring countries continued the smuggling of oil outside the country would remain a lucrative business. Arinze(2011) opined that the fuel shortage is a reflection of bad management.

Irrespective of the negative effects of fuel price increase, the Federal Government of Nigeria on January 1st,2012ceased to subsidize petroleum In Nigeria, for decades Nigerians have enjoyed low gasoline prices, Now that this benefit has ended, what are the economical implication other that the popular planed protest by various groups such as labour, occupy Nigeria and fuel subsidy, on the nation. The economical effects, without auguring for or against subsidy removal, are what this paper will try to capture. The Government of Nigeria would have to consider these effects now or deal with it In the near future.

Osogie(2012) opined that the growth of real GDP will reduce if the price of petrol is to stay as is. In addition, the rise in petrol price and the certainty of uneven prices across the federation, will add anywhere from 3 to 5 percentage points to consumer price inflation for 2012. Households' income and spending will both be affected by the rise in petrol prices. The value of minimum wage compensation will depreciate further (assuming it is finally at N18, 000) combined with the increase in inflation. At the same time, the average household's annual spending on energy goods and services will rise by about $\mathrm{N} 75,000$, and their saving rate will drop sharply. The fall in the saving rate, will erode about half of Nigeria's present middle-class citizens and further dampen the negative effects that higher prices would ordinarily have had on the economy in the short run. Consumer spending will be diminished greatly over the next few years, as citizens try to adjust and build up new savings.

\section{Statement of the Problem}

The high cost of full price has paralyzed social and economic activities in and around Kogi State and as a result, there has been a noticeable hike in prices of commodities and products in markets. A market survey carried out recently in various parts of Kogi State such as Itobe market and Anyigba market showed that the high prices were occasioned by the scarcity of petrol.Building material markets at Lokoja and Okene have recorded a tremendous price increase of late. A glance at the prices show that building materials like the complete white bath tub which used to be $N$ 9,375.00 in August 2011 now goes for N11,500.00 a bundle of zinc now cost N10,200.00 compared to N8,000 in August 2011. Also a glance at the food stuff market recorded considerable increase as a bag of rice that used to be sold for N7, 000 in 2011now sells for N9, 000.00 while Beans (brown) is now N6, 550 against N4, 500.00 in August 2011.Some of the market people spoken to attributed the increase to the removal of fuel subsidy which led to increase in fuel pump prices.

They complained that the cost of transporting the materials and commodities from the point of purchase to the place of the business has increased,consequently patronage has dwindled as a result of ever increasing prices. Transporters on their part complained that getting their tanks filled in the face of fuel scarcity is very difficult as at times their vehicles are abandoned at the filling stations for days. At other times they have to patronize the black market at a very high cost which which leads to a corresponding higher transportation costs. The problem also affects civil servants, businessmen, students and lecturers adversely. It is therefore on this backdrop that the researcher wants to examine the impact of the above enumerated problems as a result of fuel price increase on Nigerianeconomy. Therefore, the main objective of this study is to examine the impact of fuel price increase on the Nigerian economy. Specifically, the study is set to examine effect of the recent increases in fuel prices on economic growth in Nigeria; analyze effects of fuel price hike on purchasing power; examine the impact of fuel subsidy removal on the Nigerian balance of payment and 
assess Implications of increase in pump price of petroleum on food security in Nigeria. The objective of the study was guided by the following research questions: What effect has the recent increases in fuel prices on economic growth in Nigeria?To what extent have the effects of fuel price hike on purchasing power in Nigeria?What is the impact of fuel subsidy removal on the Nigerian balance of payment? And what are the implications of increase in pump price of petroleum on food security in Nigeria? The study is guided by the following hypotheses: HOl: There is no significant relationship between the recent increases in fuel prices and economic growth in Nigeria; H02: Nigeria economy is not developing because of the effect of fuel price hike on purchasing power and H03: There is no significant relationship between increase in pump price of petroleum and food securityin Nigeria

\section{Literature Review}

\subsection{Effect of the Recent Increases in Fuel Prices on Economic Growth in Nigeria}

It is a common knowledge today that fuel scarcity worsens inflation and poverty in Nigeria and many workers will lose their jobs as companies will find it difficult to cope.Arinze (2011)itemized theeffect as follows:

i. Fuel crisis paralyzed social and economic activities, it brings about socio-economic unrest which result in increase in transport fare, sky rocketing of market prices and prices of building materials.

ii. High rate of inflation: this leads to increased spending both by government and private individuals. Fuel scarcity creates inflation in both public and private life with a consequent increase in prices of goods and services.

iii. Excessive corruption and mismanagement: Fuel crisis bring about corruption by both government and private individual. Corruption however, discourages foreign direct investment.

iv. Retardation in economic growth: It slows down the pace of economic development because of its negative impact on the socio-economic life of the people.

v. Importationcost of fuel: It leads to huge and excessive public expenditure on importation of fuel to augment local production which in itself is an indication of an unhealthy economy resulting in accumulated balance of payments deficit of a country. The attendant consequences of this includes abandonment of several on-going economic and infrastructural development projects to meet the foreign exchange requirements for the purchase of refined petroleum products from overseas countries to augment local consumption, poverty and underdevelopment.

vi. Fire disaster: During fuel scarcity, the product becomes more available in the hands of unauthorized road-side dealers (black marketers) who take undue advantage of the unfortunate situation to sell the product at exorbitant prices and engage in profiteering.

The unauthorized dealers also engage in reckless storage of this product in exposed tanks, drums and buckets roadside to extort money from members of the public. This however has resulted in several economic losses, deepening underdevelopment and poverty in our society as in some cases, the exposed tanks get exploded into flames that have burnt people's houses and vehicles and even loss of life in the process.

\subsection{Effects of Fuel Price Hike on Purchasing Power}

There is no doubt that the recent increase in the price of fuel by 49 per cent, from N65 to N97, by the Federal Government of Nigeria has started to trim down the purchasing power of the people, especially the poor masses, who have always been at the receiving end of every harsh economic policy introduced by government.

Cyoh (2012) has argued that an increase of such magnitude in the current Nigerian economic context is, without doubt, a process that is either inadvertently or deliberately conceived to take money away from the pockets of all Nigerian income earners, with over 70 per cent of Nigerians who live on below N360 per day, as the prime victims.In reality, anyone in this category will end up with over 50 per cent of his daily income, which is about N155 per day, inevitably dedicated to transport costs, while the remaining is expected to cater for family feeding, health, education and other social expenses.

Olorunfemi (2012) predicted that inflation rate would fluctuate between 13 and 14 per cent for most part of 2012.An investment and research firm, Renaissance Capital said it expected inflation to rise from a projected 10 per cent to between 13 and 14 per cent between January and March and average about 15 per cent for the year, 2012.It, however, said that should the government be persuaded to phase the removal of petrol subsidy as a means of easing the burden of price increases, then the increase in inflation could be lesser than 15 per cent for the year. The inflation rate had been a 
source of worry for the Central Bank of Nigeria, which struggled throughout 2011 to reduce the figure to a single digit rate.Nigeria's inflation rates experienced a wavy flow for most parts of 2011, from January till December 2011. Although, the National Bureau of Statistics attributed the development to the upward and downward movement in the prices of food items, it also linked the movement to increase in the price of kerosene across the country.

Inflationary figure for January 2011 was 12.1 per cent as against 11.8 per cent recorded in December 2010. This, according to the NBS, was due to hike in the price of kerosene experienced across the country and increase in the prices of some household items and building materials. In the month of February, inflation declined to 11.1 per cent. As the country was trying to regain its balance, the rate yet increased to 12.8 per cent in March, the highest in the year, as a result of the major determinant, according to the monthly release by NBS.April inflation rate was put at 11.3 per cent which was slightly lower than the 12.8 recorded in March.There was a huge jump again in May from 11.3 per cent recorded earlier to 12.4 per cent. The statistical data in May revealed that the percentage increase which was higher than the corresponding level a year ago was as a result of the planting season in the country.In June, the inflation reduced to 10.2 per cent as against the corresponding month which was 12.4 per cent.

The CBN's expected single digit inflation rate was recorded for the first time in the country in July as it declined to 9.4 per cent from the June rate of 10.2 per cent.From the first single digit recorded in July, the rate also declined with 0.1 per cent as it dropped to 9.3 per cent in August.In the month of September, the inflation rate rose to 10.3 per cent as against 9.3 per cent recorded in August. The inflation rate for October 2011 rose to 10.5 per cent as against 10.3 per cent recorded in the preceding month, and was maintained at 10.5 per cent in November.The usual seasonal hike in commodity prices during Christmas was unable to push up Nigeria's inflation which rather moderated to 10.3 per cent in December 2011, slightly lower than the 10.5 per cent recorded in November.

Analysts believe that the inflation rate this year would shoot up to at least 15 per cent, even as the CBN agreed that inflation would accelerate to 14 per cent or 15 per cent by mid-year, from 10.5 per cent in November, however, taking into account the initial full removal of fuel subsidy on January 1.

The Managing Director, Sotice Investment Company Limited, Mr. AdedayoToluwase, said several millions of Nigerians would live poorer and suffer more than they had ever done in recent history in 2012. He said, "More than ever in the history of the country, more Nigerians will sink further below the poverty line. The prices of goods and services have increased at the same time that wages remain stagnant and unemployment remains a nationwide scourge. More than 70 per cent of Nigerians lack the usual or socially acceptable amount of money or material possessions needed to live a happy life. This unfortunate category of Nigerians lack material comfort and in plain language they live from hand to mouth.

"The increase in the price of fuel will automatically reduce the purchasing power of Nigerians. It will increase their fears and deteriorate their health status. Food, water and housing are three important parameters to measure the values of our lives and these things have become elusive to the masses in Nigerians. With the increase from N65 per litre to N97 per litre, Nigeria is now the most expensive place to buy petrol in all oil producing nations."It is rather paradoxical that the CBN would lend support to any policy that would instigate the rate of inflation to such an oppressive level. In successful economies elsewhere, an inflation rate above four per cent is considered as socially and economically oppressive and offensive, and government policies would be recognised to have failed. Indeed, with inflationary rate of up to 15 per cent, motivation for savings becomes meaningless.Government, however, has said that a lot of the concerns about inflation were a bit exaggerated.

Forex reserves will improve because we spend so much money importing petroleum products. If our reserves don't go up, then everybody believes that the naira is going to be weaker and we will have pressure on the currency. So, the savings from fuel subsidy will increase reserves, reduce the pressure on the currency and improve our ability to contain inflation. We may even have enough reserves to strengthen the naira."Similarly, the Managing Director, Financial Derivatives Company Limited, Mr. BismarkRewane, said in an interview, "Life may be harder for the people but I don't subscribe to the opinion of some analysts that inflation will shoot up above 20 per cent (CBN, 2005).

\subsection{Concept of Subsidy}

According to the Academics Dictionary of Economics (2006) defined subsidy - "The cash incentive given by the government to an industry with a view to lower the price of the product of the concerned industry and to raise its competitive power is known as subsidy. This may be given as a counter balancing measure to the imposition of the custom duty (In the nature of protection duty) by an importing country government. One important objective of subsidy is to keep its prices below the cost of production." 
Furthermore, subsidy can also be defined as any measure that keeps prices consumers pay for a goods or products below market levels for consumers or for producers above market. Subsidies take different forms. Some subsidies have a direct impact on price. These include grants, tax reductions and exemptions or price controls. Others affect prices or costs indirectly, such as regulations that skew the market in favour of a particular fuel, government sponsoring technology, or research and development. Thus, there are two major classes of subsidies - production subsidies which is associated with developed countries and;Consumer subsidies, which are found mainly in developing countries like Nigeria.A subsidy is a reverse tax. It is a deliberate attempt by government to support a chosen economic agent - a consumer and a producer and it can be applied in any market that involves the buying and selling of products and or services. A subsidy as defined by the OECD in a study is basically government action that decreases the consumption price of the consumer and or increases the selling price of the producer (UNEP, 2002)

Finally, subsidies enjoy widespread use in several countries and several commodities such as petroleum products, food or farm inputs liker fertilizer and machinery. Though, a subsidy can be a very powerful policy tool that can be used to address market failures or achieve social objectives. It may also be an artificial tool to skew markets and this can impose large economic costs with huge negative externalities such as corruption. Since government is the primary provider of subsidies, it is expedient that policy makers should be well equipped to decide whether, where and when to provide subsidies. It is equally important that any such subsidy injection should adequately recognise the costs to the economy of distorting competition when assessing subsidies and to identify where, if possible, such costs may be minimized.

\subsection{Role of Fuel Subsidy}

Arize(2011) maintained that the electricity is an essential tool which drives industrialization and hence a key factor in national economic growth and development. The generation of electricity is pivotal to the availability of electricity for energy consumption. There are several medium for the generation of electricity but the bulk of electricity generation in developing countries is through the use of petroleum product or fuel; Turbines are run on fuel powered generators. This implied the significance of fuel to national development. Thus whatever happens to fuel supply will has impact on economic growth and development.

Afolabi(1999) put that it has been shown in the past that any significant increase in the fuel price often cause economic recession, such as witnessed in 1973 and 1979. One way in which the government had made fuel sufficiently available and affordable to the low -income earner is through subsidy. The introduction of subsidy indirectly promote economic growth and development as a result of the affordability of the price of goods which provides an enabling point for the middle class citizen to contribute significantly to the economy. Lesson from China shows how subsidy had contributed significantly to economic growth and development. The success could be attributed to the affordability of energy and hence an increase in its demand.

Nwosu(2009) equally maintained that subsidy removal though will play significant role in nation building it is not the absolute resort to improve the economy. While it looks significantly important, there are other measures that could be adopted even without subsidy removal which would improve the economy significantly. And the presence of subsidy will play a pivotal role to the accomplishment of this measure as is being witnessed in china. The removal of government benefit to the people in the form of subsidy will have a negative impact on the low to middle income earners. The middle income earners have been identified as the group of people in the nation, whose activities mostly drive economic growth and development. The high cost of commodities following the removal of subsidy will constitute an impediment to the good plan of the government associated with subsidy removal.

\subsection{Impacts of Fuel price increase on Economy}

Fuel price increase according to Onwioduokitanda and Adenuga (2012) would have the following negative effects: -

Increase in cost of production: Removing fuel subsidy while at the same time devaluing the naira would result in increase in the cost of production for the few companies that are still existing. This would lead to more job losses (as the companies would be forced to down-size in order to survive) in addition to the unavoidable increase in the cost of the companies' products is the increase in the cost of providing services Removal of fuel subsidy would make nonsense of the proposed 2012 budget estimates because the astronomical inflation arising from subsidy removal would not have been factored into the budget. It will certainly cost much more to construct a kilometer of road or a borehole for example when subsidy is removed. In actual fact, simple photocopying paper would cost much more post subsidy removal than is the case now. So how can anyone convince us to expect more dividends of democracy when fuel subsidy is removed?

Increase in the cost of transportation: Everybody appreciates the fact that when motorists pay more for fuel, the 
transport fare increases. This has been the case even when the increase is only marginal. In the particular case where the cost of fuel is expected to double, the increase in transport fare will be astronomical. This will in turn affect everything else - school fees, house rent, just name it.

Increase in cost of living: In addition to school fees, house rent, etc. the cost of every item of food will astronomically increase with removal of fuel subsidy and, for all sane people, this is where the trouble is. When poor people are unable to eat because they cannot buy roasted corn or yam (which they usually eat as meal) as is bound to happen when fuel subsidy is removed, there will be no peace in this country. This is a fact we must accept and it is one reason why the implications of all policies must be rigorously scrutinized before decision is taken. For any responsible government this is enough reason to jettison the idea of fuel subsidy removal.

Increase in corruption: Removal of fuel subsidy and devaluation of the naira would render the salaries received by civil/public servants at all levels inadequate. The tendency is that corruption, which the government has proved incapable of fighting, would increase. This has always been the case and there is no reason why this will not happen now.I make bold to say that removal of fuel subsidy would not guarantee the construction of refineries by private companies for two reasons. First, if marketers (and this includes the companies that have been licensed to build refineries) import fuel and sell on the basis of the bogus PPPRA template when subsidy is removed, nothing will encourage them to build refineries. This is because they will make much more money through importation than they would by refining crude oil. Secondly, constructing new refineries would cost much more when fuel subsidy is removed and the naira devalued. That will also be a disincentive to building new refineries.

\subsection{Impacts of Fuel price increase on the Balance of Payment}

The relationship between fuel subsidy removal and the balance of payment is a negative one. This means that subsidy removal is not good for Balance of Payment (BOP) of Nigeria. From the above explanation of the negative effects of fuel subsidy removal, it is clear that increase in fuel pump price has an adverse effect on the standard of living of the people, since fuel is essential for the transportation of major Nigerian commodities, such as Agricultural produce and other market products. Increase in fuel price usually has serious macroeconomic effects throughout the globe, which may adversely affect economic growth and could lead to inflation and large swings in term of trade, with important balance of payments repercussions. This study reviews the immediate effects of the higher food and fuel prices on the balance of payments of net importers of these items, on overall inflation, and on poverty, within Nigeria.

It is also clear that each time there is an increase in the pump price of fuel the value of naira depreciates, which in effect, affect the purchasing power of the Naira, hence, a higher level of financial instability among Nigerians. The upsurge in the pump price may lead to an increase in poverty level hence posing a challenge to the long term vision of reducing poverty in the country. The balance of payments is badly affected because the inflation that results from fuel subsidy removal can discourage foreign investors because the naira would not have any value again. Hence, there is capital flight and Nigeria would experience unfavourable balance of payments.

Again, importers of all kinds of goods especially capital goods would incur more financial burden to import few goods. And the foreign countries would spend less to trade with Nigeria which makes them record favourable balance of trade and Nigeria recording unfavourable balance of trade.Finally, the situation is made worse when the local demand outweigh (more than) aggregate supply. This is true of high rate of consumption. This would lead to high demand for foreign goods both consumer and producers goods and intermediate goods with attendant unfavourable balance of trade.

\subsection{Effects of Recent increasesin prices of Fuel on economic growth in Nigeria}

The Federal Government of Nigeria on January 1st ceased to subsidise petroleum In Nigeria, for decades Nigerians have enjoyed low gasoline prices, Now that this benefit has ended, what are the economical implication other that the popular planed protest by various groups such as labour, occupying Nigeria and fuel subsidy, on the nation?

The Government of Nigeria would have to consider these effects now or deal with it In the near future. The growth of real (inflation-adjusted) GDP will reduce if the price of petrol is to stay as is. In addition, the rise in petrol price and the certainty of uneven prices across all 36 states of the federation, will add anywhere from 3 to 5 percentage points to consumer price inflation for 2012. Households' income and spending will both be affected by the rise in petrol prices. The value of minimum wage compensation will depreciate further (assuming it is finally at N18, 000) combined with the increase in inflation. At the same time, the average household's annual spending on energy goods and services will rise by about $\mathrm{N75}, 000$, and their saving rate dropped sharply. The fall in the saving rate, will erode about half of Nigeria's present middle-class citizens and further dampen the negative effects that higher prices would ordinarily have had on the 
economy in the short run. Consumer spending will be diminished greatly over the next few years, as citizens try to adjust and build up new savings.

\subsection{Business must pay attention to energy efficiency and create an active corporate energy strategy}

Corporations and non-energy producing firms are not left-out and will be indirectly affected by the energy price hike, affecting their bottom line. It is well documented that the Nigerian power industry barely supports 20 percent of the Nations needs; Corporations in turn will push their losses on consumers. On the other hand, the profits of energy producing companies will increase sharply. Most energy using industries will be able to pass on the higher costs of energy to their customers as it's seen on the streets of Nigeria today.GDP is expected to largely rebound from its shortterm losses since majority of Nigeria's revenue is from the sale of oil, although the shift in oil prices is likely to keep the level of GDP over the next 5 years lower than it would have been otherwise. In addition, Nigerian standard of living will be depressed to a greater extent than will GDP.

\subsection{Effects of fluctuations of price of crude oil on the price of petrol at the local filling stations}

many people believe that the increase in petrol prices will lead to sharp slowdowns, in economic growth and the risk for small businesses would be at historical highs. The global economy and most important the Nigerian economy has been at very weak points in their business cycle for the past three years, following the banking crises in Nigeria which is yet to be fully resolved. The central bank struggles throughout this period to control inflation and spending billions of dollars trying to defend the Naira, is a indicator of the general health of the economy. Nigeria's economic structure at this time is not able to respond to price shocks of over 100 percent increase today.

\section{Methodology}

The study adopted a survey research design approach to evaluate the level of effect the fuel price increase has caused on the Nigeria economy. The methodology is chosen as a means of generating reliable empirical data upon which recommendation and conclusion will be based. The population of the study is made up of all civil servants-CS, market men and women-MMW and staff in the private sectors-SPS concerned with petrol and gas affairs. A sample size of 120 persons was selected at random, using Bourley (1998) proportional allocation formula, it was distributed as follows: Civil Servants (18), market men and women (55) and staff in the private sectors (47). A pre test was conducted and outcome yield " $r$ "= 0.92 indicating a high degree of consistency and reliability. The instrument was 8- term survey questionnaire with a - 5 Likert scale response options of Very Relevant (VR), Relevant(R), No Effect (NE) Irrelevant (I), and Very Irrelevant $(\mathrm{VI})$. The questionnaire was structured in line with theresearch objectives, questions and hypothesis of the study. The Pearson product moment correlation coefficient wasused to confirm formulated hypotheses.

\section{Data Presentation, Analysis and Discussion}

The results of the analysis based on the hypotheses tested are as shown in the summary below:

Table 2: Summary of Hypotheses Test Results

\begin{tabular}{|c|c|c|c|c|c|l|}
\hline$H / N$ & QS & Cal. "r" & LS $(x)$ & Inference & Correlation & Decision \\
\hline 1 & A & 0.93 & 0.5 & $r>x$ & Highly positive & Accept Alternate \\
\hline 2 & A & 0.19 & 0.5 & $r<x$ & Low positive & Accept Null Hypothesis \\
\hline 3 & B & 0.87 & 0.5 & $\mathrm{r}>\mathrm{x}$ & Highly positive & Accept Alternate \\
\hline
\end{tabular}

Keys: HN=Hypotheses Number; QS=Questionnaire section; LS= Level of significance.

\section{Test of Hypotheses}

$\mathrm{HOl}$ : There is no significant relationship between the recent increases in fuel prices and economic growth in Nigeria.

Question 1 of the questionnaire administered:The recent increases in fuel prices affects economic growth in Nigeria. 


\begin{tabular}{|c|c|c|c|c|c|}
\hline Options & Point $(\mathrm{x})$ & Response(y) & $\mathrm{XY}$ & $\mathrm{X}^{2}$ & $\mathrm{Y}^{2}$ \\
\hline $\mathrm{VR}$ & 5 & 60 & 300 & 25 & 3,600 \\
\hline $\mathrm{V}$ & 4 & 22 & 88 & 16 & 484 \\
\hline $\mathrm{NE}$ & 3 & 10 & 30 & 9 & 100 \\
\hline $\mathrm{I}$ & 2 & 1 & 38 & 4 & 324 \\
\hline $\mathrm{VI}$ & 1 & 17 & 17 & 1 & 289 \\
\hline$\Sigma$ & 15 & 110 & 473 & 55 & 4,797 \\
\hline
\end{tabular}

Source: Fieldwork, October2014

$$
\begin{aligned}
R= & N \sum X Y-(X Y)\left(\sum Y\right) \\
& \sqrt{ }\left[N \sum X Y^{2}-(X)^{2}\right] \sqrt{ }\left[N \sum Y^{2}-(Y)^{2}\right] \\
& =5(473)-(15 \times 110) \\
& {\left[(5 X 55)-(15)^{2}\right]\left[(5 X 4,797)-(110)^{2}\right] } \\
& 2,365-1,650 \\
& \sqrt{ }(270-225)(23,985-12,100) \\
& 715 \\
& \sqrt{ }(50)(11,885) \\
& =715 \\
& 771 R=0.93(93 \%)
\end{aligned}
$$

In hypothesis1, the r calculated of $0.93 \geq 0.5$ level ofsignificance. The alternate hypothesis is accepted. This shows that there is significant relationship between the recent increases in fuel prices and economic growth in Nigeria. Though the variables have high positive correlationbut in Nigeria government under the leadership of Present Good Luck Jonathan is waxing strong to bring the situation under control.

\section{Test of hypothesis two}

H02: Nigeria economy is not developing because of the effect of fuel price hike on purchasing power.

Question 2 of the questionnaire administered:Nigeria economy is affected by fuel price hike on purchasing power

\begin{tabular}{|c|c|c|c|c|c|}
\hline Options & Point( $(\mathrm{x})$ & Response(y) & $\mathrm{XY}$ & $\mathrm{X}^{2}$ & $\mathrm{Y}^{2}$ \\
\hline $\mathrm{VR}$ & 5 & 80 & 400 & 25 & 2,025 \\
\hline $\mathrm{V}$ & 4 & 7.5 & 30 & 16 & 400 \\
\hline $\mathrm{NE}$ & 3 & 0.5 & 4.5 & 9 & 9 \\
\hline $\mathrm{I}$ & 2 & 0.5 & 1 & 4 & 81 \\
\hline $\mathrm{VI}$ & 1 & 0.5 & 0.5 & 1 & 400 \\
\hline$\Sigma$ & 15 & 90 & 355 & 55 & 4,013 \\
\hline
\end{tabular}

Source: Fieldwork, October2014

$$
\begin{aligned}
R= & N \sum X Y-(X Y)\left(\sum Y\right) \\
& \sqrt{ }\left[N \sum X Y^{2}-(X)^{2}\right] \sqrt{ }\left[N \sum Y^{2}-(Y)^{2}\right] \\
& =5(355)-(15 X 110) \\
& {\left[(5 \times 55)-(15)^{2}\right]\left[(5 \times 4,013)-(110)^{2}\right] } \\
& 1,775-1,650 \\
& \sqrt{ }(270-225)(20,065-12,100) \\
& 125 \\
& \sqrt{ }(50)(7,965) \\
& =125 \\
& 631 \mathrm{R}=0.19(19 \%)
\end{aligned}
$$

Hypothesis 2 shows that the rcalculated of $0.19 \leq 0.5$ level of significance.The null hypothesis is upheld that Nigeria economy is not developing because of the effect of fuel price hike on purchasing power. 


\section{Test of Hypothesis Three}

H03: There is no significant relationship between increases in pump price of petroleum and food security in Nigeria. Question 3 of the questionnaire administered:increases in pump price of petroleum affect food security in Nigeria.

\begin{tabular}{|c|c|c|c|c|c|}
\hline Options & Point(x) & Response(y) & $\mathrm{XY}$ & $\mathrm{X}^{2}$ & $\mathrm{Y}^{2}$ \\
\hline $\mathrm{VR}$ & 5 & 50 & 250 & 25 & 2,500 \\
\hline $\mathrm{V}$ & 4 & 19 & 76 & 16 & 361 \\
\hline $\mathrm{NE}$ & 3 & 1 & 3 & 9 & 1 \\
\hline $\mathrm{I}$ & 2 & 20 & 40 & 4 & 400 \\
\hline $\mathrm{VI}$ & 1 & 13 & 13 & 1 & 169 \\
\hline$\Sigma$ & 15 & 110 & 382 & 55 & 3,662 \\
\hline
\end{tabular}

Source: Fieldwork, October2014

$$
\begin{array}{rl}
R=N & N X Y-(X Y)\left(\sum Y\right) \\
& \sqrt{ }\left[N \sum X Y^{2}-(X)^{2}\right] \sqrt{ }\left[N \sum Y^{2}-(Y)^{2}\right] \\
& =5(382)-(15 \times 110) \\
& {\left[(5 \times 55)-(15)^{2}\right]\left[(5 \times 3,662)-(110)^{2}\right]} \\
& 1,910-1,650 \\
& \sqrt{ }(270-225)(18,310-12,100) \\
& 260 \\
& \sqrt{ }(50)(6,210) \\
& =263 \\
& 301 \mathrm{R}=0.87(87 \%)
\end{array}
$$

Hypothesis 3 revealed that the $r$ calculated of $0.87 \geq 0.5$ level ofsignificance. The alternate hypothesis is accepted. The alternate hypothesis is upheld which means that there is significant relationship between increase in pump price of petroleum and food security.

\section{Conclusion and Recommendations}

\subsection{Conclusion}

Based on the findings, the paper concludes that the economical effects, without auguring for or against subsidy removal are negative. The Government of Nigeria would have to consider these effects now or deal with it In the near future. The growth of real GDP hasreduced because of the hike in the price of fuel in Nigeria. In addition, the rise in petrol price and the certainty of uneven prices across all 36 states of the federation, will add anywhere from 3 to 5 percentage points to consumer price inflation since 2012 to date 2014. Households' income and spending have both been affected by the rise in petrol prices. More so the value of minimum wage compensation will depreciate further (assuming it is finally at N18, 000) combined with the increase in inflation. At the same time, the average household's annual spending on energy goods and services will rise by about $\mathrm{N} 75,000$, and their saving rate dropped sharply. The fall in the saving rate, will erode about half of Nigeria's present middle-class citizens and further dampen the negative effects that higher prices would ordinarily have had on the economy in the short run. Consumer spending will be diminished greatly over the next few years, as citizens try to adjust and build up new savings.

Paying high prices for petrol and using less of it will affect the demand for goods and services. Nigeria is known more as a consuming nation than a producing nation. The few production industries In Nigeria will face a daunting challenge to stay in business (cost of production will go up and demand will drop).

The effects on demand, however, have by far the greater potential impact on GDP in the short run. In a perfect world, using less energy has only a small direct effect on production because, out of all the inputs to production (labor, structures and equipment, energy, and other raw materials), energy costs account for a relatively small share of output, but In the case of Nigeria, energy is a major share of output, as organizations have to provide for their own power inhouse, such as generators sets etc and are exposed to the market as it relates to energy prices with the subsidy gone. 
The effects on demand and the consequent indirect effects on production-could be a much bigger problem, because spending more on petroleum imports and the nation's poor power sector will generally reduces spending on goods and services in Nigeria while it will increase prices on virtually every good and service.

\subsection{Recommendations}

Based on the conclusion the following recommendations have been slated:

i. Government should retain fuel subsidy while expediting the construction of the three proposed refineries.

ii. Fuel subsidy should be removed as soon as these new refineries are commissioned.

iii. The proposed rehabilitation of the existing refineries should be expedited.

iv. Government should vigorously pursue the revitalization of the railways. If only Nigerians had alternative to road transport, all this noise about fuel subsidy removal would not have been there.

v. Private companies should be encouraged to start building refineries now with the assurance that subsidy would be removed before they start production.

vi. Government should embark on full deregulation of fuel prices to ensure market competitiveness.

vii. Government should outlaw or legislate against unauthorized dealership in the sale and distribution of petroleum products to reduce the hazards of extortion, unwarranted fire incidence leading to colossal economic loss and loss of life during periods of fuel scarcity and fuel price hike.

\section{References}

Abang I. S. et al (2012). Enlightenment to the Impact of Fuel Subsidy Removal In Nigeria.

Afolabi, J. 1999 "The Oil Price of Hike Blunder", Newswatch, January 18, pp. 8-16.

Arinze P. E. 2011: "The impact ofoil price on the Nigerian economy"www.transcampus.org/journals.www.ajol.info/journals/jorind JORIND (9)1

Allwell, O. (2012). State and Local government subsidy reinvestment program www.punchang.com retrieved April23, 2012

Central Bank of Nigeria 2003: Annual Report and Statement of Account, Vol.12, CBNPublications.

Central Bank of Nigeria 2005: Economic and Financial Review, Vol.14, CBN

Food and Agriculture organization (2012) FAO bulletin 2012.

Gyoh, S. (2012) Nigeria The case against fuel subsidy and the argument for deregulated petroleum sub sectorhtt/awarenessfor. Retrieved March 19, 2014.

Gbadamosi, Kupolokun\&Oluleye 2007 "Deregulation of the Nigerian DownstreamOil sector". AbujaLukman, R. IIJ88.

Kalra K. B. (2006) Academic's Dictionary of Economics(1st Ed) Academic (India) Publishers New Delhi.

National Centre for Technology Mgt.An Agency of Fed.Ministry of Science \& Technology.

ObafemiAwolowo University, lle-Ife, Scientific\& Academic Printing.

Nwankwo, G. O. 1981: Nigeria and OPEC To be or not to be pp. 6(l-112

Nwosu, Chioma P. 2009 "Import of Fuel Prices on Inflation: Evidences from Nigeria". ResearchDepartment, Central Bank of Nigeria [SSRN:http://ssm.com/abstract=1365820]Runl, O. 2010 "Nigeria is poor because of oil alternative view publication of changeAfrica New work Africa Centre for Leadership Strategy and Development",August, 2010.

Mbendi, M.L. 2000: "Law and Petroleum Industry in Nigeria Lagos", Nigeria: African Books Publishers.

Osogie C. (2012). Nigeria LCC lists, effects of fuel subsidy removal. http://allatrica.co, retrieved 20, March, 2011

$\mathrm{OPEC}$ and the Nigerian Petroleum IndustryMba

Olorunfemi, S. 2003 "Natural Gas option in Nigeria Industrial Development Process",CBN Economic and Financial Review, Vol.14.

Onwioduokitanda E. A. and Adenuga O. 2000 "Empirical Analysis of the Demand forPetroleum Products in Nigeria". C.B.N 2000 Journal Publication pp 33-57

Osagie. E 1981: Petroleum and moneypp. 22-28.

Sikkam B. S. 1999 "Inflationary Effects of the Petroleum Industry on the NigerianEconomy" pp 128-129

Yemi I. (2012). The political economy of fuel subsidy in Nigeria http://nigeriansabroadlive.com retrieved April 12, 2014. 